\title{
Assessment of air quality and erythrocyte oxidative stress indicators of storekeepers of laboratory/industrial chemicals in owerri, Imo state, Nigeria
}

\author{
Alisi, C.S., Chikezie, P.C 1 . \\ Department of Biochemistry, Federal University of Technology, Owerri, Nigeria. \\ ${ }^{I}$ Department of Biochemistry, Imo State University, Owerri, Nigeria.
}

Submission Date: 21-11-2013

\begin{abstract}
The present study ascertained air quality (AQ) of chemical stores and level of alterations in erythrocyte oxidative stress biomarkers of storekeepers exposed to laboratory/industrial chemicals in Owerri, Imo State, Nigeria. Erythrocyte percentage methaemoglobin (\%MetHb), reduced glutathione (GSH) concentration, thiobarbituric acid reactive substances (TBARS) index and $\mathrm{H}_{2} \mathrm{O}_{2}$ induced erythrocyte haemolysis of participants were measured by spectrophotometric methods. The air levels of $\mathrm{CO}, \mathrm{NH}_{3}$ and $\mathrm{NO}_{2}$ in the chemical shops were below Environmental Protection Agency (EPA) minimum standards. Particulate matters (PM) of both control and test air samples were within EPA standards. Erythrocyte $\% \mathrm{MetHb}$ of test participants represented an increase of $61.81 \%$ compared to the control participants $(p>0.05)$, whereas erythrocyte GSH concentration of test participants showed significant difference $(p<0.05)$. Levels of $\mathrm{H}_{2} \mathrm{O}_{2}$ induced erythrocyte haemolysis was significantly $(p<0.05)$ higher than those of the corresponding control participants. The ratio of erythrocyte TBARS index of the test to the control participants was 1.4:1 approx.; $p<0.05$. The present study showed that the gas substances in chemical stores in Owerri compromised AQ with attendant potentials to cause oxidative stress and hazardous consequence to the storekeepers.
\end{abstract}

Keywords: Air quality, Methaemoglobin, Glutathione, Haemolysis, Erythrocyte, Oxidative Stress.

\section{INTRODUCTION}

Occupational hazards whereby individuals are exposure to noxious industrial/workplace chemicals come with the generation of free radicals with attendant detrimental effects on tissues, organs and biological processes, which could provoke acute or/and chronic disorders ${ }^{[1,2]}$. Free radicals react with biomolecules and cell structural components such as biomembrane and other lipid containing assemblies to yield reactive peroxides with attendant by-products, notably, malondialdehyde (MDA) and 4-hydroxyalkenals (4HNE). Lipid peroxidation is initiated

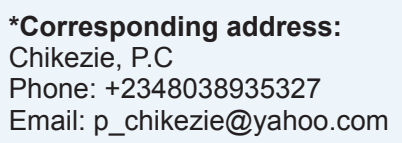

DOI: $10.5530 /$ fra.2014.1.11 by reactive oxygen and nitrogen species (RONS) such as superoxide $\left(\mathrm{O}^{2-}\right)$, peroxide $\left(\mathrm{H}_{2} \mathrm{O}_{2}\right)$ hydroxyl $(\mathrm{OH})$ and peroxynitrite $\left(\mathrm{ONOO}^{-}\right)$radicals, which may elicit oxidative stress in biologic systems. Notable antioxidant enzyme system include: superoxide dismutase (SOD), catalase (CAT) and glutathione ancillary enzymes \{glutathione peroxidase (GSH-Px), glutathione reductase (GR), glutathione S-transferase (GST) $\}$ and glucose-6-phosphate dehydrogenase (G6PD).

The present study ascertained the air quality (AQ) of chemical stores and levels of alterations in erythrocyte oxidative stress biomarkers of storekeepers exposed to laboratory/industrial chemicals in Owerri, Imo State, Nigeria.

\section{MATERIALS AND METHODS}

Study area/selection of participants: The study was conducted in Owerri Municipality, Imo State, Nigeria, 
Chikezie, et al.: Assessment of air quality and erythrocyte

which lies on rainforest belt (Latitude $5.485^{\circ} \mathrm{N}$ and Longitude $7.035^{\circ} \mathrm{E}$ ) of West Africa. Apparently healthy male storekeepers $(n=24)$, not $<5$ years of experience on the job, and control male participants $(n=26)$ between the ages of 25-35 years old were selected for this study. Exclusion criteria for participants (control and test participants) were those on vitamin supplements, smoking and alcoholism. Also, persons living with human immunodeficiency virus (HIV) and on anti-malarial drugs did not participate in this study.

Ethics: The Ethical Committee of Federal University of Science and Technology, Owerri, approved the study in compliance with the ethical principles that have their origins in the declaration of Helsinki. Before enrolment for the study, the participants involved signed an informed consent form.

Measurement of AQ: Air was measured for levels gaseous matter such as $\mathrm{CO}, \mathrm{NH}_{4}, \mathrm{H}_{2} \mathrm{~S}, \mathrm{NO}_{2}, \mathrm{SO}_{2}$ and $\mathrm{CH}_{4}$ with the aid of Multi-Functional Air Quality Measuring Instrument (MFAQMI- Testo 4352, USA- detection limit $(0.002 \mathrm{ppm})\}$. The continuous particulate monitoring ( $\beta$-gauge methods) device-KIMOTO SPM-613 was used for measurement of particulate matters(PM).

Collection and preparation of blood specimen: Blood volume of $4.0 \mathrm{~mL}$ was collected from participants by venipuncture using disposable syringe and collected in EDTA anticoagulant bottles. The erythrocytes were washed by methods described by Tsakiris et al., ${ }^{[3]}$. Platelets and leucocytes were eliminated from the pelleted erythrocytes by the methods of Kalra et al., ${ }^{[4]}$.
Erythrocyte methaemoglobin concentration: Methaemoglobin $(\mathrm{MetHb})$ concentration was measured according to the methods as described by Chikezie et al., ${ }^{[5]}$.

Erythrocyte glutathione concentration/TBARS index: The method reported by Raja et al., ${ }^{[6]}$ was used for measurement of erythrocyte GSH concentration, whereas level of thiobarbituric acid reactive substances (TBARS) was measured according to Liu et al., ${ }^{[7]}$.

Erythrocyte $\mathrm{H}_{2} \mathrm{O}_{2}$ induced haemolysis: The modified method of Dewey et al. ${ }^{[8]}$ was used for this analysis.

Statistical analyses: The data were analyzed by the use of students' $t$-distribution test of significance by Pearson and Hartley, ${ }^{[0]}$.

\section{RESULTS}

The results in Table 1 showed that gas substances in the chemical/industrial shops, which constituted as air pollutants, were above the minimum/reference values according to EPA standards. Also, for the control air samples, levels of gas substances namely; $\mathrm{CO}$ and $\mathrm{NO}_{2}$ were slightly elevated but below EPA standards $(p>0.05)$.

From Table 2, erythrocyte $\% \mathrm{MetHb}$ of the test participants represented increase of $61.81 \%$ compared to the control participants $(p>0.05)$. Levels of $\mathrm{H}_{2} \mathrm{O}_{2}$ induced erythrocyte haemolysis of the test participants was significantly $(p<0.05)$ higher than that of the corresponding control participants. The ratio of erythrocyte TBARS index of the test to the control participants was 1.4:1 approx.; $p<0.05$.

Table 1 Air quality of chemical shops in Owerri municipality

\begin{tabular}{|c|c|c|c|c|c|c|c|}
\hline \multicolumn{8}{|c|}{ Air composition } \\
\hline & $\begin{array}{c}\mathrm{NO}_{2} \\
(\mathrm{ppm})\end{array}$ & $\begin{array}{c}\mathrm{CH}_{4} \\
(\mathrm{ppm})\end{array}$ & $\begin{array}{c}\mathrm{NH}_{3} \\
(\mathrm{ppm})\end{array}$ & $\begin{array}{c}\mathrm{CO} \\
(\mathrm{ppm})\end{array}$ & $\begin{array}{c}\mathrm{SO}_{2} \\
(\mathrm{ppm})\end{array}$ & $\begin{array}{c}\mathrm{H}_{2} \mathrm{~S} \\
(\mathrm{ppm})\end{array}$ & $\begin{array}{c}\mathrm{PM} \times 10^{-3}(\mathrm{mg} / \\
\left.\mathrm{m}^{2}\right)\end{array}$ \\
\hline Test & $0.77 \pm 0.14^{a}$ & $1.17 \pm 0.41^{a}$ & $8.67 \pm 1.03$ & $57.50 \pm 15.56^{a}$ & $0.32 \pm 0.04^{a}$ & $0.65 \pm 0.10$ & $13.90 \pm 5.39^{a}$ \\
\hline Control & $0.30 \pm 0.05^{a}$ & $0.30 \pm 0.10^{a}$ & ND & $10.00 \pm 2.72^{b}$ & $0.21 \pm 0.03^{a}$ & ND & $0.50 \pm 0.19^{b}$ \\
\hline EPA-S & 0.12 & 0.30 & $<1.0$ & 9.0 & 0.34 & NA & 15 \\
\hline
\end{tabular}

EPA-S: Environmental Protection Agency Standards; ND: Not Detected; NA: Not Available; PM: Particulate Matter. Means in the columns with the same letters are not significantly different at $\mathrm{p}>0.05$.

Table 2 Erythrocyte oxidative stress indicators of shopkeepers in Owerri municipality

\begin{tabular}{|c|c|c|c|c|}
\hline \multicolumn{5}{|c|}{ Oxidative stress indicators } \\
\hline Participants & $\%$ MetHb & \%Haemolysis & GSH (mg/dL) & TBARS (mmol/L) \\
\hline Control $(n=56)$ & $1.44 \pm 0.04^{\mathrm{a}}$ & $10.53 \pm 1.23^{a}$ & $64.94 \pm 1.52^{\mathrm{a}}$ & $2625.56 \pm 12.34^{a}$ \\
\hline Test $(n=53)$ & $2.23 \pm 0.05^{a}$ & $58.43 \pm 1.42^{b}$ & $53.43 \pm 1.27^{b}$ & $3624.82 \pm 10.45^{\mathrm{b}}$ \\
\hline
\end{tabular}

Means in the column with the same letters are not significantly different at $\mathrm{p}>0.05$. 


\section{DISCUSSION}

The present study showed that chemical stores in Owerri were polluted, especially with the occurrence of $\mathrm{NO}_{2}, \mathrm{CO}$, $\mathrm{NH}_{4}$ and $\mathrm{CH}_{4}$ above minimum levels of EPA standards. Previous researches have shown that the major sources of $\mathrm{NO} 2$ and $\mathrm{CO}$ in urban areas are mostly from traffic and electricity generators emissions ${ }^{[1]}$. The chemical stores under the present investigation are located along the busy streets of the municipality. Therefore, the locations of these stores could be one amongst other contributory factors that accounted for the observed high levels of these gaseous pollutants.

Biological and epidemiological studies have provided evidence in support of the fact that toxic air pollutants are among the major underlying causative factors of oxidative stress ${ }^{[10]}$. According to Agrawal and Sharma ${ }^{[11]}$, pesticides induced oxidative stress in mammalian systems was the outcome of distortions in the balance between tissue ROS and antioxidant levels, which engendered tissue damage to onset of several pathologic challenges and finally apoptosis.

Findings from the present study showed that the intrinsic $\mathrm{AQ}$ in the chemical stores altered some erythrocyte oxidative stress indicators of individuals exposed to the various gas substances investigated. Similarly, Nikolić et al., ${ }^{[12]}$ had previously reported the detrimental consequences on erythrocyte functional indices in children exposed to polluted air. In addition, methane-induced hemolysis of human erythrocytes had been demonstrated by Batliwala et al., ${ }^{[13]}$. From the present findings, the depleting levels of erythrocyte GSH of the test participants could have been one of several factors responsible for increased tendency of $\mathrm{H} 2 \mathrm{O} 2$ induced erythrocyte haemolysis of these individuals. From another perspective, because the last stage of lipid peroxidation results to the formation of aldehydes, notably, malondialdehyde (MDA) and other reactive products; the so-called TBARS, by extension caused elevation of erythrocyte TBARS index in the test participants, which affirmed comparatively higher levels of lipid peroxidation in individuals exposed to polluted air emanating from the laboratory/industrial chemicals. Paradoxically, evidence from the present study showed that these agents that promoted erythrocyte membrane lipid peroxidation did not cause toxic methaemoglobinemia in the study groups. Toxic methaemoglobinemia is diagnostic when erythrocyte $\% \mathrm{MetHb}>15 \%$. The results therefore suggest that the level of air pollution in the various chemical stores did exhibit the capacity to overwhelm erythrocyte reductive systems responsible for maintaining haemoglobin in the ferrous state $\left(\mathrm{Fe}^{2+}\right)$. The present study showed that the gas substances and related pollutants in chemical stores in Owerri compromised AQ with attendant potentials to elicit oxidative stress and hazardous consequence to the storekeepers.

\section{REFERENCE}

1. Lodovici M, Bigagli E. Oxidative Stress and Air Pollution Exposure: J. Toxicol. 2011; 2011:1-9.

2. Kumar EP, Mukherjee R, Senthil R, Parasuraman S, Suresh B. Evaluation of oxidative stress and antioxidant status in patients with cardiovascular disease in rural populations of the Nilgiris, South India. ISRN Pharmacol. 2012; 2012:941068.

3. Tsakiris S, Giannoulia-Karantana A, Simintzi I, Schulpis KH. The effect of aspartame metabolites on human erythrocyte membrane acetylcholinesterase activity. Pharmacol. Res. 2006; 53:1-5.

4. Kalra VK, Sikka SC, Sethi GS Transport of amino acids in gamma-glutamyl transpeptidase-implanted human erythrocytes. J. Biol. Chem. 1981; 256: 55-67.

5. Chikezie PC, Akuwudike AR, Chikezie CM. Membrane stability and methaemoglobin content of human erythrocytes incubated in aqueous leaf extract of Nicotiana tabacum product. Free Rad. Antiox. 2012; 2(4):56-61.

6. Raja S, Ahmed N, Kumar V, Mukherjee K, Bandyopadhyan A, Mukherjee KP. Antioxidant effect of Cytisus scoparius against carbon tetrachloride treated liver injury in rats. J. Ethanopharmacol. 2007; 109:41-7.

7. Liu J, Edamatsu R, Kabuto $\mathrm{H}$, Mori A. Antioxidant action of Guilingii in the brain of rats with $\mathrm{FeCl}_{3}$ induced epilepsy. Free Rad. Biol. Med. 1990; 9:451-4.

8. Dewey MJ, Brown JL, Nallaseth FS. Genetic differences in red cell osmotic fragility: analysis in allophenic mice. Blood. 1982; 59:986-9.

9. Pearson ES, Hartley HQ. Biometric Tables for Statistians. 3rd edition. Cambridge University Press, London. 1966.

10. Rim K-T. Oxidative DNA damages by chemical exposures at work. Adv. Biosci. Biotechnol. 2012; 3:957-71.

11. Agrawal D, Sultana P. Biochemical and structural alterations in rat erythrocytes due to hexachlorocyclohexane exposure. Food Chem. Toxicol. 1993; 31:443-8.

12. Nikolić M, Nikić D, Stanković A. Effects of air pollution on red blood cells in children. Polish J. of Environ. Stud. 2008; 17(2):267-71.

13. Batliwala H, Somasundaram T, Uzgiris EE, Makowski L. Methane-induced hemolysis of human erythrocytes. Biochem. J. 1995; 307:433-8. 